\title{
Rol van besigheidsprosesherontwerp in die formulering van 'n inligtingstegnologiestrategie vir 'n onderneming
}

\author{
M. du Plessis* \\ Price Waterhouse MCS, Posbus 783027, Sandton, 2146 Republiek van Suid-Afrika \\ Marina_du_Plessis@South-Africa.notes.PW.com \\ T.J.D. Bothma \\ Departement Inligtingkunde, Universiteit van Pretoria, Pretoria, 0002 Republiek van Suid-Afrika \\ Bothma@libarts.up.ac.za
}

Ontvang April 1997; aanvaar Junie 1997

\begin{abstract}
Role of business process re-engineering in the formulation of an information technology strategy for an organization. In this study it was concluded that business process re-engineering usually has a resulting impact on information technology, and therefore on the information technology strategy of an enterprise. Selected findings on the effect of business process re-engineering (BPR) on information technology strategies, made during the course of this study, include: information technology is an integral part of BPR; either information technology or BPR can be the driver of a re-engineering project; BPR hightens the status of information technology within an enterprise; BPR has an effect on the way information is utilized; information scientists, information technology specialists and business experts are essential for any re-engineering team; BPR affects the nature of the information technology strategy by linking it to the business strategy and BPR will necessitate the regular revision of the information technology strategy. Business process re-engineering will alter the way in which information technology strategies have been perceived and applied in enterprises.
\end{abstract}

\begin{abstract}
Besigheidsprosesherontwerp het 'n definitiewe impak op inligtingstegnologie en derhalwe op 'n inligtingstegnologiestrategie van 'n onderneming. Geselekteerde bevindinge wat tydens hierdie studie gemaak is, sluit die volgende in: inligtingstegnologie is ' $n$ integrale deel van besigheidsprosesherontwerp; beide inligtingstegnologie en besigheidsprosesherontwerp kan die aandrywers wees van 'n besigheidsprosesherontwerpprojek; besigheidsprosesherontwerp verhoog die status van inligtingstegnologie in 'n onderneming; inligtingkundiges, inligtingstegnologiespesialiste sowel as besigheidspesialiste is noodsaaklik as lede van 'n besigheidsprosesherontwerpspan; besigheidsprosesherontwerp raak die aard van 'n inligtingstegnologiestrategie deurdat dit koppel aan die besigheidstrategie; besigheidsprosesherontwerp sal die gereelde aanpassing van 'n inligtingstegnologiestrategie noodsaaklik maak. Die eindresultaat is dus dat besigheidsprosesherontwerp die wyse waarop inligtingstegnologiestrategieë saamgestel en aangewend word, beïnvloed.
\end{abstract}

*Outeur aan wie korrespondensie gerig moet word.

Inligtingstegnologiestrategieë word dikwels saamgestel om 'n onderneming funksioneel meer effektief en doeltreffend te maak. Die moontlikheid bestaan wel dat 'n inligtingstegnologiestrategie ' $n$ onderneming se inligtingstegnologie kan rig om bestaande prosesse en funksies meer effektief te maak, maar dit beteken nie dat die bestaande prosesse reeds hulle optimale vlak van effektiwiteit en doeltreffendheid bereik het nie. Die implikasie hiervan is dan dat so ' $n$ inligtingstegnologiestrategie net in ' $n$ beperkte mate daarin kan slaag om ' $n$ onderneming deur die gebruik van inligtingstegnologie meer effektief en doeltreffend te maak. Om dus sy volle potensiaal te kan bereik, sal die strategie besigheidsprosesherontwerp in ag moet neem indien dit ' $n$ bydrae wil lewer in die verbetering van besigheidsprosesse as sodanig en derhalwe die totale bedryf van die onderneming.

Die noodsaak van die oplossing van die probleem lê in die feit dat bogenoemde scenario in die praktyk nie altyd plaasvind nie - dat besigheidsprosesherontwerp en die formulering van ' $n$ inligtingstegnologiestrategie gesien word as twee aparte aktiwiteite en dat dit deur verskillende partye uitgevoer word sonder dat die partye mekaar raadpleeg. Dit is egter in die belang van enige onderneming dat hierdie aktiwiteite nie in isolasie sal plaasvind nie.

\section{Probleemstelling}

'n Inligtingstegnologiestrategie word saamgestel om, deur die aanwending van inligtingstegnologie, 'n onderneming funksioneel meer effektief te maak. In die praktyk word inligtingstegnologiestrategieë egter dikwels geformuleer bloot op grond van bestaande inligtingstegnologie en inligtingstegnologie-opsies binne 'n onderneming, sowel as op grond van bestaande besigheidsprosesse. Hoewel die moontlikheid bestaan dat ' $n$ inligtingstegnologiestrategie bestaande prosesse meer effektief kan maak deur byvoorbeeld verhoogde akkuraatheid van inligting en verbeterde toeganklikheid tot inligting, beteken dit nog nie dat die prosesse wat geoutomatiseer word, reeds maksimum effektiwiteit bereik het nie. Om dus sy volle potensiaal te kan bereik, sal die inligtingstegnologiestrategie as plan vir die seleksie en implementering van inligtingstegnologie, besigheidsprosesherontwerp, waar besigheidsprosesse herontwerp word om aan te pas by die moderne, hoogs kompeterende besigheidsomgewing, in ag moet neem. Die kernprobleem volgens die navorsers is in hoe 'n mate 
inligtingstegnologiestrategieë geraak word deur besigheidsprosesherontwerp waar die toepassing van inligtingstegnologie ter sprake is, aangesien hierdie twee konsepte dikwels in die praktyk as twee aparte aktiwiteite, wat geen invloed op mekaar uitoefen nie, gesien word.

Daar is ' $n$ verskeidenheid subprobleme wat uit hierdie tema voortspruit. Hierdie subprobleme wat aangespreek sal word, sluit die volgende in:

- Staan inligtingstegnologie slegs ondersteunend tot besigheidsprosesherontwerp, of is dit ' $n$ integrale deel daarvan, en hoe beïnvloed dit die formulering van 'n onderneming se inligtingstegnologiestrategie?

- Is inligtingstegnologie of besigheidsprosesherontwerp die aandrywer van die onderlinge wisselwerking tussen hierdie twee opsies en watter invloed het dit op die formulering van 'n onderneming se inligtingstegnologiestrategie?

- In hoe ' $n$ mate beïnvloed besigheidsprosesherontwerp die status van inligtingstegnologie en derhalwe 'n inligtingstegnologiestrategie binne 'n onderneming?

- Sal die impak wat besigheidsprosesherontwerp op die formulering van 'n inligtingstegnologiestrategie mag hê, enige invloed op inligting, en die wyse waarop dit as sodanig benut word, hê?

- Is inligtingstegnologiespesialiste of inligtingkundiges verantwoordelik vir besigheidsprosesherontwerp? Indien wel, hoe beïnvloed dit die vaardighede en kundigheid waaroor hulle moet beskik? Indien inligtingstegnologiespesialiste of inligtingkundiges nie daarvoor verantwoordelik is nie, wie is? Hoe kan hierdie spesialiste en inligtingstegnologiespesialiste hulle werk integreer?

- Hoe beïnvloed besigheidsprosesherontwerp die aard van 'n inligtingstegnologiestrategie?

\section{Metodologie}

Die artikel is gebaseer op 'n omvattende literatuurstudie. Bestaande bronne is gesintetiseer om ' $n$ ander perspektief daarop te bied.

\section{Definisie van besigheidsprosesherontwerp}

Besigheidsprosesherontwerp analiseer, herdink, herevalueer en herorganiseer ' $n$ onderneming se besigheidsprosesse en die strategieë, sisteme en strukture wat daarmee saamgaan, vinnig en op radikale wyse met die hulp van evolusionêre hulpmiddele en metodes, soos menslike, operasionele, inligtings- en inligtingstegnologiese hulpmiddele, om dramatiese verbeteringe teweeg te bring ten opsigte van die onderneming se produktiwiteit, kwaliteit, buigbaarheid, spoed, akkuraatheid, winsgewendheid, kliëntetevredenheid en volgehoue kompeterende voordeel (Du Plessis 1996:13).

\section{Wisselwerking tussen besigheidsprosesheront- werp, inligtingstegnologie en inligtingstegnologie- strategieë}

Is inligtingstegnologie slegs ondersteunend tot besigheidsprosesherontwerp, of is dit ' $n$ integrale deel daarvan?

Inligtingstegnologie speel in baie gevalle wel 'n groot rol in besigheidsprosesherontwerp, hoewel dit nie noodwendig 'n integrale deel daarvan hoef te wees nie. Die groot belang van inligtingstegnologie kom egter meestal in by sleutel- of kernprosesse van ondernemings, waar dit dikwels noodsaaklik is om tegnologie aan te wend om 'n sogenaamde kwantumsprong in prestasie mee te bring. Die navorsers is van mening dat dit veral ter sprake kom wanneer daar 'n hoogs mededingende mark is en ondernemings van dieselfde standaard inligtingstegnologie gebruik moet maak as hulle konkurrente om mededingend te wees. Dit is tans veral van toepassing op die Suid-Afrikaanse mark, waar sanksies opgehef is en daar sprake is van 'n meer vrye, ope handel. SuidAfrikaanse ondernemings word nou gedwing om te kompeteer met handelaars wêreldwyd, wat beteken dat hulle ten opsigte van prosesse sowel as inligtingstegnologie kompeterend moet kan wees.

Die gevolgtrekking wat uit die studie gemaak kan word, is dat inligtingstegnologie nie as ' $\mathrm{n}$ reël noodsaaklik is vir besigheidsprosesherontwerp nie, hoewel dit in baie gevalle noodsaaklik mag wees. Die navorsers is verder van opinie dat, hoewel inligtingstegnologie ' $n$ integrale, noodsaaklike deel van besigheidsprosesherontwerp mag uitmaak, dit meer in 'n ondersteunende hoedanigheid plaasvind. Die rede hiervoor is dat inligtingstegnologie gewoonlik nie die aandrywer van besigheidsprosesherontwerp is nie, maar besigheidsprosesherontwerp die anwending van inligtingstegnologiebenutting in ' $n$ onderneming rig. Die twee konsepte is egter onlosmaaklik verbind deurdat geleenthede vir die benutting van inligtingstegnologie waar moontlik geïdentifiseer moet word voordat besigheidsprosesse herontwerp word (Luftman, Lewis \& Oldach 1993:211).

In bestuursliteratuur is dit algemeen bekend dat, hoewel inligtingstegnologie dikwels slegs 'n ondersteunende rol in besigheidsprosesherontwerp speel, dit tog ' $\mathrm{n}$ integrale deel uitmaak van besigheidsprosesherontwerp en dat die twee onlosmaaklik aan mekaar verbind is (Davenport \& Short 1990:25; MacArthur, Crosslin \& Warren 1994:241; Vitiello 1993:52).

Die feit dat inligtingstegnologie ' $n$ integrale deel uitmaak van besigheidsprosesherontwerp, het egter sekere implikasies vir die formulering van ' $n$ inligtingstegnologiestrategie:

- Dit beteken dat die rol van besigheidsprosesherontwerp in ag geneem moet word wanneer die inligtingstegnologiestrategie geformuleer word, om sodoende alles in ag te neem wat moontlik 'n invloed op die onderneming as sodanig en daarom ook op die inligtingstegnologiestrategie mag hê. 
- Dit beteken dat die inligtingstegnologiestrategie baie nouer gekoppel sal wees aan die onderneming se besigheidstrategie, aangesien inligtingstegnologie benut kan word met die oog op besigheidsprosesherontwerp, wat deel uitmaak van die besigheidstrategie.

- Die inligtingstegnologiestrategie sal meer gereeld aangepas moet word om by te hou met veranderinge wat gereeld aangebring word as gevolg van besigheidsprosesherontwerp. Die inligtingstegnologiestrategie sal aangewend moet word om die kompeterende potensiaal van die onderneming te optimaliseer (Adamson \& Chong 1994:6; Clemons 1991:23; Luftman, Lewis \& Oldach 1993:211).

- Die inligtingstegnologiestrategie sal inligtingstegnologiestelsels aan besigheidsaktiwiteite moet koppel aangesien die stelsels 'n groot koste-element van 'n aktiwiteit en die gepaardgaande proses is. Dit sal nuwe inligtingstegnologie-ontwikkelings realisties haalbaar mak ten opsigte van veranderende aktiwiteite en prosesse.

- 'n Inligtingstegnologiestrategie sal as gevolg van hierdie nuwe benadering tot die formulering daarvan, gesien word as ' $n$ algemene bestuursprosedure ten opsigte van die onderneming as geheel (Jones 1994:374; Kovacevic \& Majluf 1993:78).

- Wanneer besigheidsprosesherontwerp ter sprake is in ' $n$ onderneming, behoort daar altyd binne die inligtingstegnologiestrategie 'n datageoriënteerde, sowel as 'n prosesgeoriënteerde perspektief sigbaar te wees (De Beer 1992:76).

- Die fokus van 'n inligtingstegnologiestrategie sal ook in die lig van besigheidsprosesherontwerp verskuif vanaf inligtingstegnologie as sodanig, na geoutomatiseerde besigheidsprosesse en hoe inligtingstegnologie die onderneming behulpsaam kan wees in die bereiking van besigheidsdoelwitte deur die verbetering en ondersteuning van besigheidsprosesse (De Beer 1992:13).

\section{Inligtingstegnologie en besigheidsprosesherontwerp: onderlinge wisselwerking}

Die navorsers het drie duidelike tendense in die wisselwerking van inligtingstegnologie en besigheidsprosesherontwerp geïdentifiseer. Die eerste is waar besigheidsprosesherontwerp die aandrywer is vir die verkryging en benutting van inligtingstegnologie. Die tweede opsie is waar inligtingstegnologie besigheidsprosesherontwerp aandryf en die derde opsie is waar daar sprake is van 'n kringloop tussen die twee, naamlik waar inligtingstegnologie aanleiding gee tot besigheidsprosesherontwerp wat weer aanleiding gee tot die aanpassing van inligtingstegnologie.

\section{Besigheidsprosesherontwerp as aandrywer vir die verkryging en benutting van inligtingstegnologie}

In hierdie geval word besigheidsprosesherontwerp gedoen op grond van die onderneming se besigheidstrategie. Die besigheidstrategie en besigheidsprosesherontwerp bepaal hoe die inligtingstegnologie-infrastruktuur aangepas en bestuur moet word om die nodige inligtingsprodukte en -dienste te kan lewer (Carlton 1990:181; Grover, Teng \& Fiedler 1993:434; Henderson \& Venkatraman 1993:130; Prairie 1993:23). Bagnall (1992:20) meen dat die herontwerp van besigheidsprosesse ' $n$ beter aanduiding van nuwe inligtingsbehoeftes sal gee.

Die navorsers is van opinie dat hierdie benadering vir ' $n$ onderneming van groot waarde kan wees. Dit is volgens die navorsers veral van toepassing wanneer die spilpunt van die hele herontwerpproses nie die daarstelling van 'n inligtingstegnologiestelsel is nie, maar eerder die daarstelling van meer effektiewe besigheidsprosesse. Dit kan veral gebeur waar ondernemings geldelike probleme ervaar en inligtingstegnologiestelsels dus nie ' $n$ nommer een prioriteit is nie, maar iets is wat steeds in gedagte gehou word. In so 'n geval word inligtingstegnologie dikwels aangekoop op grond van die ekstra verdienste wat verkry word deur die bedryf van meer effektiewe besigheidsprosesse wat daargestel is. Dit kan ook 'n gewilde benadering wees vir ondernemings wat glad nie swaar steun op die gebruik van inligtingstegnologie nie.

Hierdie benadering het egter sekere implikasies vir die formulering van ' $n$ inligtingstegnologiestrategie:

- Inligtingstegnologie mag, in sommige gevalle, steeds gesien word as slegs ' $n$ ondersteuningsmeganisme vir die bedryf van die onderneming en die inligtingstegnologiestrategie sal dienooreenkomstig geformuleer moet word.

- Inligtingstegnologie sal die herontwerpte besigheidsprosesse in ag moet neem om optimaal te kan funksioneer. Dit beteken dat die inligtingstegnologie-infrastruktuur sowel as die ontwerp en funksionering van inligtingstegnologie nagegaan en verander moet word om aan te pas by die herontwerpte prosesse.

- Die inligtingstegnologiestrategie sal duidelik die rol van inligtingstegnologie in die onderneming moet uitspel.

\section{Inligtingstegnologie as aandrywer vir besigheidsprosesher-} ontwerp

Inligtingstegnologie as sodanig kan daartoe lei dat besigheidsprosesherontwerp in 'n onderneming plaasvind. 'n Onderneming mag dalk inligting oor inligtingstegnologie bekom, wat nuwe geleenthede bied waaraan daar nie voorheen gedink is of aandag aan geskenk is nie. Die bewustheid van die funksionaliteit van inligtingstegnologie mag idees oor hoe die onderneming se besigheidsprosesse bedryf word, vernuwe, en sodoende aanleiding gee tot die herontwerp van prosesse binne die onderneming met die oog op die kombinering daarvan met die spesifieke inligtingstegnologie.

Die navorsers is van mening dat hierdie benadering ook van groot belang vir sekere ondernemings kan wees. Dit is veral die geval waar inligtingstegnologie ' $n$ baie prominente rol in die onderneming speel en ondernemings gewoonlik op die voorpunt van tegnologie-ontwikkelings staan. Besigheidsprosesherontwerp sal dan dikwels gedoen word op grond van die bestaande inligtingstegnologie in die onderneming of op grond van nuwe inligtingstegnologie wat aangekoop word deur die onderneming. 
Hierdie benaderings het sekere implikasies vir die formulering van ' $n$ inligtingstegnologiestrategie:

- Die inligtingstegnologiestrategie mag geformuleer word voordat besigheidsprosesherontwerp plaasvind. Dit sal veral die geval wees waar die onderneming reeds oor inligtingstegnologie beskik wat behoue gaan bly tydens die herontwerpprojek. Die herontwerp sal dus geskied rondom hierdie inligtingstegnologie. Dieselfde sal geld waar 'n keuse gemaak word aangaande nuwe inligtingstegnologie wat in 'n onderneming geïmplementeer gaan word, wat die aard van besigheidsprosesse kan verander.

- Indien inligtingstegnologie, eerder as besigheidsprosesherontwerp, gesien word as aandrywer vir die onderneming, sal die inligtingstegnologiestrategie meer gereeld aangepas moet word om voorsiening te maak vir die opgradering van inligtingstegnologie of die aankoop van nuwe inligtingstegnologie.

- Die inligtingstegnologie, en daarom ook die inligtingstegnologiestrategie, sal aangepas moet word om die kompeterende potensiaal van die onderneming te verhoog (Adamson \& Chong 1994:6; Clemons 1991:23; Luftman, Lewis \& Oldach 1993:211).

- Waar besigheidsprosesherontwerp gaan volg op die formulering van die inligtingstegnologiestrategie, sal die strategie voorsiening moet maak vir die toepassing en benutting van inligtingstegnologie oor funksionele grense heen, aangesien besigheidsprosesherontwerp nie gebonde is aan funksionele grense nie.

\section{Inligtingstegnologie/besigheidsprosesherontwerp 'kringloop'}

Besigheidsprosesherontwerp kan lei tot die implementering van nuwe, gesofistikeerde inligtingstegnologiestelsels. Nuwe inligtingstegnologie-ontwikkelinge kan op hulle beurt weer ' $n$ besigheidstrategie beïnvloed en selfs ' $n$ nuwe besigheidstrategie moontlik maak (byvoorbeeld deur nuwe markgeleenthede) en sodoende 'n kompeterende voordeel vir 'n onderneming skep. Daarna kan die nuwe inligtingstegnologie wat geïmplementeer word weer lei tot nuwe besigheidsgeleenthede, wat kan lei tot besigheidsprosesherontwerp. Hierdie benadering impliseer dat daar ' $n$ uiters noue band moet wees tussen die inligtingstegnologiestrategie, besigheidstrategie, organisatoriese infrastuktuur en die prosesse van 'n onderneming. Hierdie is ' $\mathrm{n}$ bestuursbenadering wat bepaal hoe inligtingstegnologie die besigheidstrategie kan aanvul, wat lei tot die transformasie van die onderneming se infrastruktuur (besigheidsprosesherontwerp). Dit kan op sy beurt weer lei tot die aanpassing van inligtingstegnologie.

Die navorsers is van opinie dat die inligtingstegnologie/ besigheidsprosesherontwerp 'kringloop' die aangewese benadering is vir die meerderheid ondernemings. Die navorsers meen dat, in die geval van die 'kringloop', maksimale effektiwiteit bereik kan word deurdat alle moontlikhede ten opsigte van besigheidsprosesherontwerp en inligtingstegnologie in ag geneem word wanneer prosesse herontwerp word én wanneer die inligtingstegnologiestrategie geformuleer word. Die ideale 'kringloop' sal gekarakteriseer word deur 'n inligtingstegnologie-ondersoek binne die onderneming om na te gaan welke tegnologie tans gebruik word. Daarna sal 'n deeglike ondersoek gedoen word na die stand van inligtingstegnologie op die mark. Sake soos funksionaliteit, aanpasbaarheid en koste sal in ag geneem word in die ondersoek. Nadat hierdie verkennende ondersoek gedoen is, sal besigheidsprosesse herontwerp word met inagneming van die funksionaliteit wat nuwe inligtingstegnologie die onderneming moontlik kan bied. Nadat die prosesse herontwerp is, kan finale keuses uitgeoefen word aangaande die verkryging en implementering van toepaslike inligtingstegnologie en die inligtingstegnologiestrategie kan dienooreenkomstig geformuleer word om hierdie inligtingstegnologie se aanwending te rig.

Implikasies van hierdie benadering op die formulering van 'n inligtingstegnologiestrategie, sluit die volgende in:

- 'n Aanvanklike studie van moontlikhede ten opsigte van inligtingstegnologie sal uitgevoer moet word, alvorens die besigheidsprosesherontwerp 'n aanvang kan neem en die inligtingstegnologiestrategie geformuleer kan word.

- Hierdie benadering sal vereis dat die inligtingstegnologiestrategie gekoppel word aan spesifieke besigheidsaktiwiteite en -prosesse binne die onderneming om maksimum effektiwiteit van beide besigheidsprosesherontwerp en die inligtingstegnologiestrategie te verkry.

- In hierdie geval sal die inligtingstegnologiestrategie ook heelwat aangepas moet word as deel van die vloeiende 'kringloop'. Hoewel dit baie insette sal verg, sal dit die gehalte en resentheid van beide inligtingstegnologie en besigheidsprosesherontwerp verseker.

- Dit beteken dat die rol van besigheidsprosesherontwerp in ag geneem moet word wanneer die inligtingstegnologiestrategie geformuleer word.

- Die inligtingstegnologiestrategie sal aangewend moet word om die kompeterende potensiaal van die onderneming te optimaliseer.

- Die inligtingstegnologiestrategie sal inligtingstegnologiestelsels aan besigheidsaktiwiteite moet koppel aangesien die stelsels 'n groot koste-element van 'n aktiwiteit en die gepaardgaande proses is.

- 'n Inligtingstegnologiestrategie sal inligtingsbehoeftes op 'n heel ander manier moet aanspreek.

- 'n Inligtingstegnologiestrategie sal as gevolg van hierdie nuwe benadering tot die formulering daarvan, gesien word as 'n algemene bestuursprosedure ten opsigte van die onderneming as geheel.

- Wanneer besigheidsprosesherontwerp ter sprake is in ' $n$ onderneming, behoort daar altyd binne die inligtingstegnologiestrategie 'n datageoriënteerde, sowel as 'n prosesgeoriënteerde perspektief sigbaar te wees.

- Die fokus van ' $n$ inligtingstegnologiestrategie sal ook in die lig van besigheidsprosesherontwerp verskuif vanaf inligtingstegnologie as sodanig, na geoutomatiseerde besigheidsprosesse en hoe inligtingstegnologie die onderneming behulpsaam kan wees in die bereiking van 
besigheidsdoelwitte deur die verbetering en ondersteuning van besigheidsprosesse.

\section{Samevatting}

In die literatuur is dit duidelik dat outeurs meen dat elk van die bogenoemde benaderings 'n moontlikheid vir 'n onderneming is, afhangend van die spesifieke omstandighede en behoeftes van die onderneming en die mate van kompleksiteit wat ter sprake is.

Die navorsers meen egter dat dit nie net 'n vraag is of besigheidsprosesherontwerp die aandrywer van inligtingstegnologie is of andersom nie, maar dat die hele kwessie ' $n$ heelwat breër konteks het wat ook hier bespreek moet word. Hierdie breër konteks sluit die onderneming se totale besigheidstrategie en die rol wat inligting binne 'n onderneming vervul, in.

Die algemene opinie onder navorsers en praktisyns is dat 'n onderneming sy besigheidstrategie (wat infrastuktuur, prosesse en personeelbestuur insluit) en inligtingstegnologiestrategie in ooreenstemming met mekaar moet ontwikkel en aanpas sodat beide op mekaar gerig is en mekaar ondersteun en kan uitvoering gee aan die visie en missie van die onderneming en dit sodoende kompeterend maak binne die mark deur verhoogde effektiwiteit en doeltreffendheid (Hammer 1990:112; MacDonald, 1991c:313; Teng, Grover \& Fiedler 1994:97). Die belang van die koppeling van die strategieë is daarin geleë om te verseker dat prioriteite en doelwitte konsekwent gebruik word in die formulering van die strategieë sodat almal dieselfde doel nastreef, en dat hulpbronne optimaal geallokeer kan word (Luftman, Lewis \& Oldach 1993:206). Dit is ook belangrik om sodoende te verseker dat inligtingstegnologie optimaal benut word binne 'n onderneming (Henderson \& Venkatraman 1993:4). Laastens is dit belangrik dat die besigheidstrategie, inligtingstegnologiestrategie, infrastruktuur en prosesse van 'n onderneming in balans met mekaar sal wees, aangesien 'n wanbalans weens verandering kan lei tot verswakte funksionering van die ander elemente indien hulle nie dienooreenkomstig verander word nie (Hammer \& Champy 1993:81; Luftman, Lewis \& Oldach 1993:217).

Volgens die meerderheid outeurs is die besigheidstrategie die aandrywer van ' $n$ inligtingstegnologiestrategie (Coates 1992:1; Kaye 1993:356; Luftman, Lewis \& Oldach 1993:205; Peppard 1993:16). Die navorsers meen dat hierdie siening korrek is. Dit moet egter binne die raamwerk van die drie benaderings wat tevore bespreek is, gesien word. Die besigheidstrategie bepaal die rigting wat die onderneming wil inslaan en spel die visie, missie en doelwitte van die onderneming uit. Uiteraard sal die aard van enige bykomende strategie hierdeur bepaal en gelei word, aangesien die bereiking van die visie, missie en doelwitte van die onderneming sy lewensvatbaarheid bepaal. Dit beteken egter nie dat die inligtingstegnologiestrategie 'ondergeskik' is aan die besigheidstrategie nie - dit is immers 'n riglyn vir die benutting van inligtingstegnologie wat die bedryf van sekere prosesse moontlik maak of meer effektief maak.
Watter rol die besigheidstrategie en inligtingstegnologiestrategie weens die koppeling daarvan egter teenoor mekaar inneem, maak geen verskil aan die implikasies vir die formulering van die inligtingstegnologiestrategie nie. Die implikasies wat die navorsers geïdentifiseer het, sluit die volgende in:

- Die koppeling van die besigheidstrategie en die inligtingstegnologiestrategie het implikasies ten opsigte van die implementering van die twee strategieë. Die navorsers is van mening dat die implementering van die inligtingtegnologiestrategie sowel as die besigheidstrategie as gekoördineerde projekte aangepak en bestuur moet word.

- Indien die besigheidstrategie en die inligtingstegnologiestrategie aan mekaar gekoppel word, beteken dit dat daar nie net meer beantwoord moet word aan individue en afdelings se inligtings- en inligtingstegnologiebehoeftes nie. Die navorsers meen dat dit dus 'n perspektief oor funksionele grense heen sal vereis aangesien die inligtingstegnologiebehoeftes binne die konteks van besigheidsprosesse en -aktiwiteite geïdentiseer word.

- Wanneer die besigheidstrategie en inligtingstegnologiestrategie in ooreenstemming met mekaar ontwikkel word, sal die inligtingstegnologie waarskynlik 'n wyer reeks aangeleenthede in ag neem en aanspreek, aangesien dit nou nie meer slegs op inligtingstegnologie as sodanig gefokus is nie. Carlton (1990:181) meen dat die volgende sake aangespreek sal moet word: watter inligtingstegnologie-alternatiewe van toepassing is op die onderneming se unieke omstandighede; watter gevolge elk van hierdie alternatiewe sal hê ten opsigte van die inligtingstegnologiestelsels as sodanig; watter organisatoriese implikasies elk van die alternatiewe inhou; watter kompeterende voordele elk van die alternatiewe inhou en laastens wat die kostes en risiko's is wat elk van die alternatiewe vir die onderneming as geheel inhou.

- Die ooreenstemmende ontwikkeling van die inligtingstegnologiestrategie en die besigheidstrategie beteken dat die inligtingstegnologiestrategie 'n datageoriënteerde sowel as prosesgeoriënteerde perspektief sal toon om sodoende die besigheid as geheel in ag te neem (De Beer 1993:76). Dit sluit aan by die vroeëre punt wat die navorsers uitgelig het oor die feit dat besigheidsprosesherontwerp 'n prosesgeoriënteerde benadering tot gevolg het wat oor alle funksionele grense heen strek.

Invloed van besigheidsprosesherontwerp op die status van inligtingstegnologie en 'n inligtingstegnologiestrategie

Volgens die navorsers bied inligtingstegnologie baie aan ondernemings ten opsigte van mededingende voordeel, wat die status van inligtingstegnologie derhalwe verhoog. Clemons (1991:23) noem dat ondernemings inligtingstegnologie kan gebruik om kostes te verminder, produkgehalte op te gradeer, kliëntediens te verbeter of selfs om kliënte se bedryfsake met die onderneming se eie te integreer om herhaalde besigheid te verseker. 
Reponen (1993:101) meen dat juis besigheidsprosesherontwerp gelei het tot die verhoogde status wat inligtingstegnologie tans in sommige ondernemings beleef. Volgens hierdie outeur het internasionale kompetisie die druk om prosesse te herontwerp, verhoog. Dit het 'n verandering meegebring ten opsigte van ondernemings se oriëntasie - dit het verander vanaf funksionele oriëntasie na 'n prosesoriëntasie. Gevolglik sal selfs geïsoleerde funksies nou betrek word by herontwerpprojekte. Die bestuur van prosesse kan slegs suksesvol gedoen word met die hulp van effektiewe inligtingstegnologiestelsels wat ingeligte besluitneming moontlik maak. Vanuit hierdie oogpunt gesien, is inligtingstegnologie en derhalwe inligtingstegnologiestrategieë van strategiese belang vir ondernemings.

Weens hierdie mededingende voordeel wat inligtingstegnologie vir 'n onderneming bied en weens die feit dat dit direk aan die bereiking van besigheidsdoelwitte gekoppel word en as deel van die globale bestuursprosedure gesien word, word inligtingstegnologie se status tans in baie ondernemings verhef tot dieselfde vlak as dié van die besigheidstrategie.

\section{Impak van besigheidsprosesherontwerp op die formule-} ring van ' $n$ inligtingstegnologiestrategie

Volgens die navorsers het die impak wat besigheidsprosesherontwerp op die formulering van 'n inligtingstegnologiestrategie het, definitief ' $n$ invloed op inligting en die wyse waarop dit as sodanig benut word.

Die impak wat besigheidsprosesherontwerp op inligting as sodanig en op die benutting daarvan kan hê, kan as volg beskryf word:

- Aangesien daar ten opsigte van besigheidsprosesherontwerp sprake is van 'n prosesoriëntasie, beteken dit dat inligting nie meer in funksionele eenhede as hulpbron beskikbaar gestel en benut sal word nie, maar oor die hele onderneming heen. Dit beteken drastiese veranderinge in die opname van inligting in stelsels. Inligting hoef nou slegs een maal opgeneem te word en organisasiewyd (met ander woorde oor funksionele grense heen) beskikbaar gestel te word vir almal se gebruik. So sal duplisering van inligting uitgeskakel word. Dit beteken ook dat werknemers makliker toegang sal hê tot inligting in ander afdelings, wat voor besigheidsprosesherontwerp dalk moeilik herwinbaar was.

- Inligtingstegnologie wat effektief benut word om besigheidsprosesse te ondersteun of om dit moontlik te maak, kan aan ' $n$ onderneming ' $n$ groot mededingende voordeel bied. Die effektiewe benutting van inligtingstegnologie impliseer egter dat die inligting wat daarin vervat word, ook effektief benut word en daarom vir die onderneming 'n strategiese hulpbron is wat lei tot die bereiking van die onderneming se doelwitte en derhalwe mededingende voordeel aan die onderneming kan bied.

- As gevolg van die invloed van besigheidsprosesherontwerp op inligtingstegnologie, sal inligting aan sekere prosesse en aktiwiteite binne die prosesse gekoppel word om te verseker dat dit die betrokke prosesse na behore ondersteun of moontlik maak. Datamodelle van die spesifieke onderneming sal opgestel moet word om te bepaal watter inligting waar benut word en hoe die inligting vloei. Inligtingsbehoeftes sal ook nie meer per funksionele eenheid bepaal word nie, maar ooreenkomstig prosesse, met ander woorde organisasiewyd.

- Aangesien besigheidsprosesherontwerp ander vereistes aan inligtingstegnologie en daarom aan inligting stel, sal databasisse waarskynlik aangepas moet word om hierdie nuwe inligtingsbehoeftes en inligtingsvloei te bevredig.

- As gevolg van al die bogenoemde, sal daar ook meer aandag geskenk moet word aan die opvoeding ten opsigte van die gebruik van inligtingstegnologiestelsels en die inligting daarin vervat. Gebruikers moet opgelei word om bewus te wees van die moontlikhede wat die benutting van inligting inhou en hoe die inligting gemanipuleer kan word ten opsigte van die benutting daarvan.

- Aangesien die inligtingstegnologiestrategie gesien word as deel van die oorhoofse bestuursproses van die onderneming, is dit vanselfsprekend dat daar ook sprake moet wees van die bestuur van inligting as sodanig, asook vir die benutting daarvan. Inligting moet bestuur word deur middel van die daarstelling van 'n inligtingsbeleid wat riglyne sal neerlê oor die verkryging, vaslegging, beskikbaarstelling en benutting van inligting. Ten opsigte van die benutting van inligting is bestuur ' $n$ belangrike maatreël om te verseker dat sekuriteit in inligtingsisteme ingebou word om vertroulikheid te verseker waar nodig.

\section{Kundiges en benutting van hulle vaardighede}

Verantwoordelikheid vir professionele insette tydens besigheidsprosesherontwerp

MacDonald (1991b:305) meen dat 'n kundige ten opsigte van inligtingstegnologie- en inligtingstelsels betrokke moet wees by ' $n$ besigheidsprosesherontwerpprojek aangesien so 'n persoon progressiewe denke aan die dag kan lê aangaande die potensiaal van inligtingstegnologie, maar wat daarteenoor ook bewus sal wees van die slaggate van die implementering daarvan.

Die navorsers is ook van mening dat inligtingkundiges en inligtingstegnologiespesialiste betrokke moet wees by besigheidsprosesherontwerp om die rol van inligtingstegnologie te bepaal en te verseker dat inligtingstegnologie op die effektiefste wyse moontlik aangewend sal word tydens en ná die herontwerpproses. Elk van die kundiges het 'n spesiale bydrae om te lewer: inligtingkundiges op die gebied van inligtingsorganisering en -herwinning, en inligtingstegnologiespesialiste op die gebied van apparatuur. Albei kan 'n oorkoepelende bydrae lewer ten opsigte van programmatuur.

Vaardighede en kundighede waaroor inligtingstegnologiespesialiste en inligtingkundiges moet beskik

Die fokus wat inligtingstegnologiespesialiste dikwels op inligtingstegnologie se rol plaas, kan gevare vir 'n herontwerpprojek inhou. 
'There is too often an implicit assumption that the thinking and problem solving styles of the IT professionals and users of the systems are similar. Very often, IT professionals assume that all problems have a technical solution and in failing to see the political nature of organisations fail to take proper account of problems of vested interest in implementation' (Peppard \& Steward 1993:291).

Uit die bogenoemde paragraaf is dit duidelik dat inligtingkundiges en inligtingstegnologiespesialiste oor addisionele vaardighede en kennis moet beskik. Inligtingstegnologiespesialiste of inligtingkundiges moet beslis oor bestuursvaardighede en -kennis beskik om sodoende die rol van inligtingstegnologie binne die globale bestuurskonteks te kan identifiseer en om 'n dieper begrip te kan hê vir besigheidsprosesherontwerp (Broadbent \& Weill 1991:17; Luftman, Lewis \& Oldach 1993:207; Peppard 1993:19).

\section{Ander relevante spesialiste en vaardighede waaroor hulle moet beskik}

Blennerhassett \& Galvin (1993:440) meen dat topbestuur 'n bydrae tot die herontwerpspan kan lewer ten opsigte van die formulering van 'n visie vir die toekoms vir die betrokke onderneming. Die senior bestuur van enige onderneming is ook gewoonlik betrokke by 'n besigheidsprosesherontwerpprojek (Blennerhassett \& Galvin 1993:44; Broadbent \& Weill 1991:7; MacDonald 1991b:305; Peppard \& Steward 1993: 282-283). Blennerhassett \& Galvin (1993:44) meen dat baie min verandering ooit in ondernemings plaasvind indien senior bestuur nie betrokke is by die veranderingsproses nie. Bestuur moet dus die stimulus vir verandering bied. Bestuurders het egter gewoonlik 'n gebrek aan kennis ten opsigte van die moontlikhede wat inligtingstegnologie aan ondernemings bied. ' $n$ Begrip aangaande inligtingstegnologie moet gekweek word sodat ingeligte besluitneming kan plaasvind (Broadbent \& Weill 1991:17; MacDonald 1991a:161).

Elke projek het ook projekbestuurders en 'n projekspan wat bestaan uit sleutelwerknemers van die onderneming wat verantwoordelik is vir die implementering van die verandering. Volgens die navorsers se praktykervaring is hierdie sleutelwerknemers gewoonlik nie deel van senior bestuur nie, maar op ' $n$ aanstellingsvlak net onder dit. Hierdie persone het gewoonlik ' $n$ redelik uitgebreide kennis aangaande die bedryf van die onderneming waar hulle werk en is daarom vir die onderneming van groot belang ten opsigte van besigheidsprosesherontwerp. Indien hierdie persone se samewerking en goedkeuring ('buy-in') nie verkry word nie, is die kanse goed dat die onderneming se besigheidsprosesherontwerpprojek nie baie suksesvol sal wees nie.

\section{Integrasie van verskillende spesialiste se werk}

Elk van die verskillende tipes werknemers en spesialiste het 'n eie rol te vertolk in die herontwerpspan. Hierdie rolle mag egter nie in konflik met mekaar wees nie - dit moet mekaar aanvul sodat goeie spanwerk 'n suksesvolle projek kan verseker.

Blennerhassett en Galvin (1993:440) meen dat topbestuur 'n bydrae tot die herontwerpspan kan lewer ten opsigte van die formulering van 'n visie vir die toekoms vir die betrokke onderneming. Hierdie persone kan ook optree as leiers en toekenners van hulpbronne. Hulle posisie in die onderneming bied, volgens die outeurs, aan hulle ' $n$ unieke beeld van die onderneming as geheel en 'n geleentheid om op te tree as katalisators van verandering in die onderneming.

MacDonald (1991b:305) onderskei tussen die rolle van topbestuur en senior bestuur as deel van die herontwerpspan. Volgens hom is die rol van topbestuur om te verseker dat die hele span hulle denke vernuwe. Hulle rol is verder om seniorbestuurslede, wat baie nouer betrokke gaan wees by die implementering van die verandering, te sensitiseer vir die verandering en alles wat daarmee saamgaan, en te verseker dat senior bestuur hulle ten volle verbind om die herontwerpprojek 'n sukses te makk. Topbestuur se betrokkenheid kan help om fokus en momentum te behou tydens moeilike fases in die projek en om bruikbare ervaring en kennis met almal wat deel is van die projekspan te deel.

Henderson en Venkatraman (1993:9-10) gee 'n duidelike uiteensetting van hulle siening aangaande die rolle van elk van die lede van ' $n$ besigheidsprosesherontwerpspan. Volgens hierdie outeurs moet topbestuur verantwoordelik wees vir die formulering van die besigheidstrategie, terwyl die inligtingstegnologie- of inligtingstelselbestuurder verantwoordelik moet wees vir die inligtingstegnologiestrategie. Die rol van uitvoerende bestuurslede is om die visie vir inligtingstegnologie daar te stel terwyl die inligtingstegnologiebestuurder hierdie visie moet omskakel na taktiese planne binne die inligtingstegnologiestrategie. Hierdie siening word gedeel deur Ewart (1988:173) wat byvoeg dat projekbestuurders saam met inligtingstegnologiebestuurders werk ten opsigte van die implementering van veranderings, hetsy tegnologiese veranderinge of prosesveranderinge.

Peppard (1993:2) en Firdman (1991:3) meen ook dat daar in meeste ondernemings ' $n$ groot gaping bestaan tussen bestuurslede en inligtingstegnologiewerkers. Om hierdie gaping te oorbrug en te verseker dat inligtingstegnologie tot mededingende voordeel van die onderneming aangewend word, is dit nodig dat alle bestuurslede 'n oorhoofse kennis van inligtingstegnologie sal hê om die tegnologie se vaardighede te begryp, asook die geleenthede wat dit bied en die strategiese vraagstukke wat dit na vore bring.

MacDonald (1991b:306) meen dat dit baie sal help om 'n 'proseskonsultant' aan te stel wat 'n uitstekende fasiliteerder is, om te verseker dat die beste uit die ervaring, kennis en verbeelding van alle deelnemers getrek en benut word. Die navorsers meen dat bestuurskonsultante hier ' $n$ baie belangrike rol as fasiliteerders kan speel, aangesien hierdie persone 
dikwels 'n uitgebreide kennis het aangaande die optimale bedryf van besighede en beskik oor kennis in verskeie spesialisasievelde. Hierdie mense is gewoonlik goeie kommunikeerders en kan met sukses as fasiliteerders, koördineerders en bestuurders van 'n herontwerpprojek optree aangesien hulle oor objektiwiteit beskik en al voorheen deel was van besigheidsprosesherontwerpprojekte en dus kennis het aangaande die totaliteit van sodanige projekte.

Ten slotte kan gesê word dat, sonder spanwerk, geen besigheidsprosesherontwerpprojek kan slaag nie.

'It will be up to corporate leaders to create a vision: of competitive dominance rather than mere parity; of team work and team reward rather than internal competition for coveted individual honours ...' (Johansson et al. 1993:205).

\section{Invloed van besigheidsprosesherontwerp op die aard van die inligtingstegnologiestrategie}

Die navorsers het enkele sake geïdentifiseer waar die aard van die inligtingstegnologiestrategie wel geraak sal word:

- 'n Inligtingstegnologiestrategie sal nouer gekoppel moet wees aan die besigheidstrategie.

- 'n Besigheidsprosesherontwerpprojek sal 'n impak hê op die benutting van inligting as sodanig. Die inligtingstegnologiestrategie sal dus klem moet lê op die gebruik van inligtingstegnologie om die inligting binne die onderneming makliker toeganklik en meer bruikbaar te maak in die regte formaat, op die regte tyd en plek, vir die regte persoon.

- Die kostes verbonde aan die inligtingstegnologiestrategie mag aansienlik hoër wees as wat verwag word as gevolg van die prosesoriëntasie, wat baie groter menslike insette gaan verg, asook kostes om al die inligtingstegnologie aan te pas by die nuwe inligtingstegnologiestrategie.

Die navorsers meen dat die veranderinge nie van so ' $n$ groot omvang sal wees dat dit die inherente aard van die inligtingstegnologiestrategie sal verander nie.

\section{Gevolgtrekking}

Uit die voorgaande bespreking kan duidelik gesien word dat besigheidsprosesherontwerp ' $n$ beduidende impak op die formulering van ' $n$ onderneming se inligtingstegnologiestrategie het. Dit het verreikende implikasies vir die status van inligtingstegnologie as entiteit binne die onderneming, en derhalwe ook 'n impak op die belang van inligting as strategiese hulpbron. Ondernemings wat besigheidsprosesherontwerp aanpak, sal dus moet besef dat so 'n projek baie goeie beplanning sal verg en baie deursettingsvermoë sal vereis, aangesien dit ' $n$ veel wyer impak op die onderneming het as wat meeste mense besef.

\section{Summary}

This study concludes that there is a close relationship between business process re-engineering, information technology and information technology strategies. The importance of business process re-engineering lies in the fact that it leads to new, critical perspectives on operational processes, a better understanding of the role of information technology as a resource within the change process, and a new insight into the corporate culture and the role thereof within an enterprise. The study also indicates that information technology is a strategic matter. The long-term nature of the investment in information technology and the time that it takes to develop information technology systems, requires extensive strategic planning, which necessitates an information technology strategy. Information and information technlogy permeates the organizational structure and management, and it influences interfaces with an enterprise's external environment. Effective information technology strategies are therefore essential. Information technology is an integral part of business process re-engineering. Information technology offers new management and business opportunities, for example competitive advantage in the market place, higher productivity and better performance, the facilitation of new methods of managing and organizing, and the development of new business opportunities.

Business process re-engineering has a definitive impact on the formulation of an information technology strategy. Although information technology is not necessarily essential for business process re-engineering, it is an integral part in most instances. Both business process re-engineering and information technology can be the driver of a re-engineering project, and they can even drive each other on a rotative basis. This has many implications for the content of an information technology strategy. An example could be that the information technology strategy and the business strategy of an enterprise must be more closely linked than ever before. Business process re-engineering also hightens the status of information technology and the information technology strategy in an enterprise. An information technology strategy is seen as part of the overall management process. Business process re-engineering can also influence the way in which information technology is utilized, for example through more effective organization of and access to information. Information scientists, information technology specialists as well as management should be part of the business process reengineering team. These people should also take ownership of the information technology strategy. Business process reengineering also has an impact on the nature of an information technology strategy. The information technology strategy must, for example, be more closely related to the business strategy. Adjusting and updating the information technology strategy is also influenced by business process reengineering. Both will have to be done on a more regular basis. The information technology strategy is not developed at a specific stage during business process re-engineering. Despite this, it is important to involve all team members at the start of a re-engineering project. It is concluded that business process re-engineering, as a relatively new concept, leads to 
profound changes and far-reaching consequences in enterprises in terms of business processes, information technology and the enterprise's information technology strategy.

\section{Erkenning}

Hierdie artikel is geskryf ter vervulling van die vereistes van die graad MBibl wat in 1996 deur eersgemelde outeur aan die Universiteit van Pretoria behaal is.

\section{Verwysings}

Adamson, N. \& Chong, G. 1994. Business process reengineering: why return to the drawing board? An empirical research report presented to the Department of Information Systems, University of Cape Town.

Bagnall, R. 1992. Environmental management systems: developing an IT strategy. Logistics information management, 5(4):19-20.

Blennerhassett, L. \& Galvin, E. 1993. The strategic dimension, in IT strategy for business, edited by Joe Peppard. London:

Pitman:26-52.

Broadbent, M. \& Weill, P. 1991. Developing business and information strategy alignment: a study in the banking industry. Working Paper no. 7. Melbourne: Graduate School of Business:1-23.

Carlton, D.J. 1990. Information technology strategy in harmony with business, in InfoJapan '90: information harmonizing with society: proceedings of the InfoJapan '90 Computer Conference, October 2-5, 1990, Tokyo, Japan, edited by H. Ishida. Amsterdam: North Holland:176-184.

Clemons, E.K. 1991. Corporate strategies for information technology: a resource-based approach. Computer, 24(11):23-33.

Coates, E. 1992. Management issues of distributed environments. Capacity management review, 20(12):1-5, 12.

Davenport, T.H. \& Short, J.E. 1990. The new industrial engineering: information technology and business process redesign. Sloan management review, 31(4):11-27.

De Beer, J.F. 1992. Strategic information systems planning: an architectural framework. MA dissertation, University of South Africa, Pretoria.

Du Plessis, M. 1996. Die rol van besigheidsprosesherontwerp in die formulering van ' $n$ inligtingstegnologiestrategie vir 'n onderneming. MBibl-verhandeling, Universiteit van Pretoria.

Ewart, R.W. 1988. Towards an information technology strategy. International journal of institutional management, 12(2):171175.

Firdman, H.E. 1991. Strategic information systems: forging the business and technology allowance. New York: McGraw-Hill.

Grover, V., Teng, J.T.C., \& Fiedler, K.D. Information technology enabled business process redesign. Omega, 21(4):433-447.

Hammer, M. 1990. Reengineering work: don't automate, obliterate. Harvard business review, 68(4):104-112.

Hammer, M. \& Champy, J. 1993. Reengineering the corporation: $a$ manifesto for business revolution. New York: Harper Business.
Henderson, J.C. \& Venkatraman, N. 1993. Strategic alignment: leveraging information technology for transforming organizations. IBM systems journal, 32(1):4-16.

Johansson, H.J., McHugh, P., Pendlebury, A.J. \& Wheeler, W.A. 1993. Business process reengineering: breakpoint strategies for market dominance. Chichester: Wiley.

Jones, M. 1994. Don't emancipate, exaggerate: rhetoric, reality and re-engineering, in Transforming organizations with information technology, edited by R. Baskerville et al. North Holland: Elsevier Science B.V.:357-378.

Kaye, G.R. 1993. Developing an information technology strategy: an example from distance learning in management. International journal of information management, 13(50):355-371.

Kovacevic, A. \& Majluf, N. 1993. Six stages of IT strategic management. Sloan management review, 34(4):77-87.

Luftman, J.N., Lewis, P.R. \& Oldach S.H. 1993. Transforming the enterprise: the alignment of business and information technology strategies. IBM systems journal, 32(1):198-221.

Macarthur, P.J., Crosslin, R.L. \& Warren, J.R. 1994. A strategy for evaluating alternative information system designs for business process reengineering. International journal of information management, 14(4):237-251.

MacDonald, K.H. 1991a. Business strategy development, alignment, and redesign, in The corporation of the 1990's: information technology and organizational transformation, edited by Michael S. Scott Morton. New York: Oxford University Press:159-188.

MacDonald, K.H. 1991b. The value process model, in The corporation of the 1990's: information technology and organizational transformation, edited by Michael S. Scott Morton. New York Oxford University Press:299-309.

MacDonald, K.H. 1991c. The strategic alignment process, in The corporation of the 1990's: information technology and organizational transformation, edited by Michael S. Scott Morton. New York: Oxford University Press:310-322.

Peppard, J. 1993. Information, technology, and strategy, in IT strategy for business, edited by Joe Peppard. London: Pitman: 125.

Peppard, J \& Steward, K. 1993. Managing change in IS/IT implementation, in IT strategy for business, edited by Joe Peppard. London: Pitman:269-291.

Prairie, P. 1993. An American Express/IBM consortium benchmarks information technology. Planning review, 21(1):22-27.

Reponen, T. 1993. Strategic information systems - a conceptual analysis. Journal of strategic information systems, 2(2):100-104

Teng, T.C., Grover, V. \& Fiedler, K.D. 1994. Re-designing business processes using information technology. Long range planning, 27(1):95-106.

Vitiello, J. 1993. Setting a course for radical change. Journal of business strategy, 14(6):52-57. 